\title{
IDŐJÁRÁS
}

Quarterly Journal of the Hungarian Meteorological Service

Vol. 123, No. 3, July-September, 2019, pp. 329-349

\section{Approximation of wind speed distributions with theoretical distributions of meteorological stations located in different orographic conditions}

\author{
István Hadnagy ${ }^{*}, 1,2$ and Károly Tar ${ }^{1,3}$ \\ ${ }^{1}$ Department of Meteorology, University of Debrecen, \\ Egyetem Square 1, H-4010 Debrecen, Hungary \\ ${ }^{2}$ Department of Biology and Chemistry \\ Ferenc Rákóczi II. Transcarpathian Hungarian Institute \\ Kossuth Square 6, UA-90202 Berehove, Ukraine \\ ${ }^{3}$ Institute of Tourism and Geography, College of Nyiregyháza, \\ Sóstói Road 31/B, H-4400 Nyíregyháza, Hungary \\ *Corresponding author E-mail: hadistvan@gmail.com
}

(Manuscript received in final form June 13, 2018)

\begin{abstract}
This research analyses the daily average wind speed time series of ten Transcarpathian meteorological stations in the period from 2011 to 2015 with the help of statistical methods. We approximated the empirical frequency distribution of measured daily average wind speeds by means of theoretical distributions. The results of the fitting test showed that among the applied theoretical distributions, irrespective of orographic conditions, the Weibull distribution is proved to be the most suitable. However, fitting the Weibull distribution depends on the methods of determining parameters $k$ and $c$. By means of the best fitting parameters, the distribution density function and some of its indices at the altitude of $80 \mathrm{~m}$ were worked out contrary to the anemometer altitude that is often the hub height of industrial wind turbines, thus estimating the wind conditions of the area from wind energy utilization point of view.
\end{abstract}

Key-words: wind speed, wind speed distribution, distribution analysis, Weibull distribution, Transcarpathia 


\section{Introduction}

In the process of characterization of wind power resources, the average annual wind speed is often given regarding a particular area. Figures showing wind conditions mostly display averages of long-term. However, a single data is not enough for characterization of wind power resources as far as power output is proportional to the third power of wind speed (Patay, 2003). This kind of negligence, or rather averaging, can cause significant deviation in the process of estimating annual energy potentials. Considering energy utilization point of view, it is much more essential to know the frequency of those wind speeds that are suitable for energy production. This can be demonstrated by processing statistical data and the figure showing the frequency of wind speed. By approximation of the empirical frequency distribution of wind observations, we can obtain numerous statistical and energy indices. The statistical distribution functions potentially suitable for this purpose include: Weibull distribution, Rayleigh-distribution, normal distribution, log-normal distribution, square-root normal distribution, and gamma distribution. In wind climatology, the above-mentioned distributions are most frequently applied (Bonfils, 2011; Tar, 2008; Kravchyshyn et al., 2016). Among these, the advantage of applying doubleparameter Weibull distribution lies in the fact that the distribution parameters are determined at anemometer altitude, and as a result, the values of this measurement level can be used to calculate the values of other altitudes, i.e., wind speed distribution can be described for other altitudes as well. This is used in determining wind potential. Therefore, theoretical distribution fitting plays central role in the wind energy studies. This method has been widely applied in such analyses (Dévényi and Gulyás, 1988; Bartholy and Radics, 2000; Patay, 2003; Radics, 2004; Hunyár et al., 2004; Liubimov et al., 2011; Morgan et al., 2011; Hou et al., 2012; Sobchenko and Khomenko, 2015; Kravchyshyn et al., 2016). Weibull distribution has two parameters $(k$ and $c)$ due to asymmetrical distribution, where $k$ stands for shape parameter (a dimensionless number) and $c$ stands for scale parameter $(\mathrm{m} / \mathrm{s})$, these can be calculated based on the available database. Parameters $k$ and $c$ valid at anemometer altitude can be determined in several ways (Justus et al., 1978; Tar, 2008; Costa Rocha et al., 2012; Kidmo et al., 2015; Kravchyshyn et al., 2016). Weibull distribution is related to several other probability distributions. Depending on $k$ values, the distribution density function significantly changes, while $c$ takes values typical for local wind conditions. When $k=1$ exponential distribution is obtained, while if $k=2$, Rayleigh-distribution is resulted, while when the value is close to $k=3.5$, the distribution is almost symmetric, thus being very close to normal distribution (Troen and Petersen, 1989). At 13 measurement points in Hungary, the average value of $k$ is 1.44 (Bartholy and Radics, 2000). In Ukraine, Sobchenko and Khomenko (2015) analyzed the wind data of Lviv, Kyiv, Odesa, Kryvyi Rih, Simferopol, Dnipro, Donetsk in 2001-2008 and came to the conclusion that parameter $k$ of the Weibull distribution has the following values: 1.36 in Lviv and 1.7 in Odesa, while parameter $c$ changes from 2.74 in Lviv to 4.81 in Simferopol. 
The aim of our research is to determine the parameters of statistical distribution functions on the basis of a daily average wind speed data series, to approximate and describe the empirical wind speed distributions of measuring stations in various orographic conditions. This is the most important in wind climatology. Knowing the characteristics of theoretical distribution, we can conclude the structure of empirical distribution and estimate wind potential at a particular measurement point.

\section{Data and methods}

The data series used come from 10 Transcarpathian (Ukraine) operating meteorological stations. The geographical locations of the stations are shown in Fig. 1 and Table 1 showing these stations' exact geographical coordinates, their altitude above sea level, as well as the altitude of the wind-gauge above ground level. The period under analysis lasted from January 1, 2011 to December 31, 2015. In our research, we used the daily average wind speed of the meteorological observatories. The data series were given us by the Transcarpathian Hydrometeorological Center (THMC). During the examined period there were no changes in the stations' geographical position and in the anemometer's altitude above ground level, thus wind measurement conditions did not change.

The observation stations in Fig. 1 are situated in various orographic environment. The relative difference in altitude between the stations situated at the lowest (Uzhhorod, $112 \mathrm{~m}$ ) and highest (Pozhyzhevs'ka, $1451 \mathrm{~m}$ ) altitudes is $1339 \mathrm{~m}$.

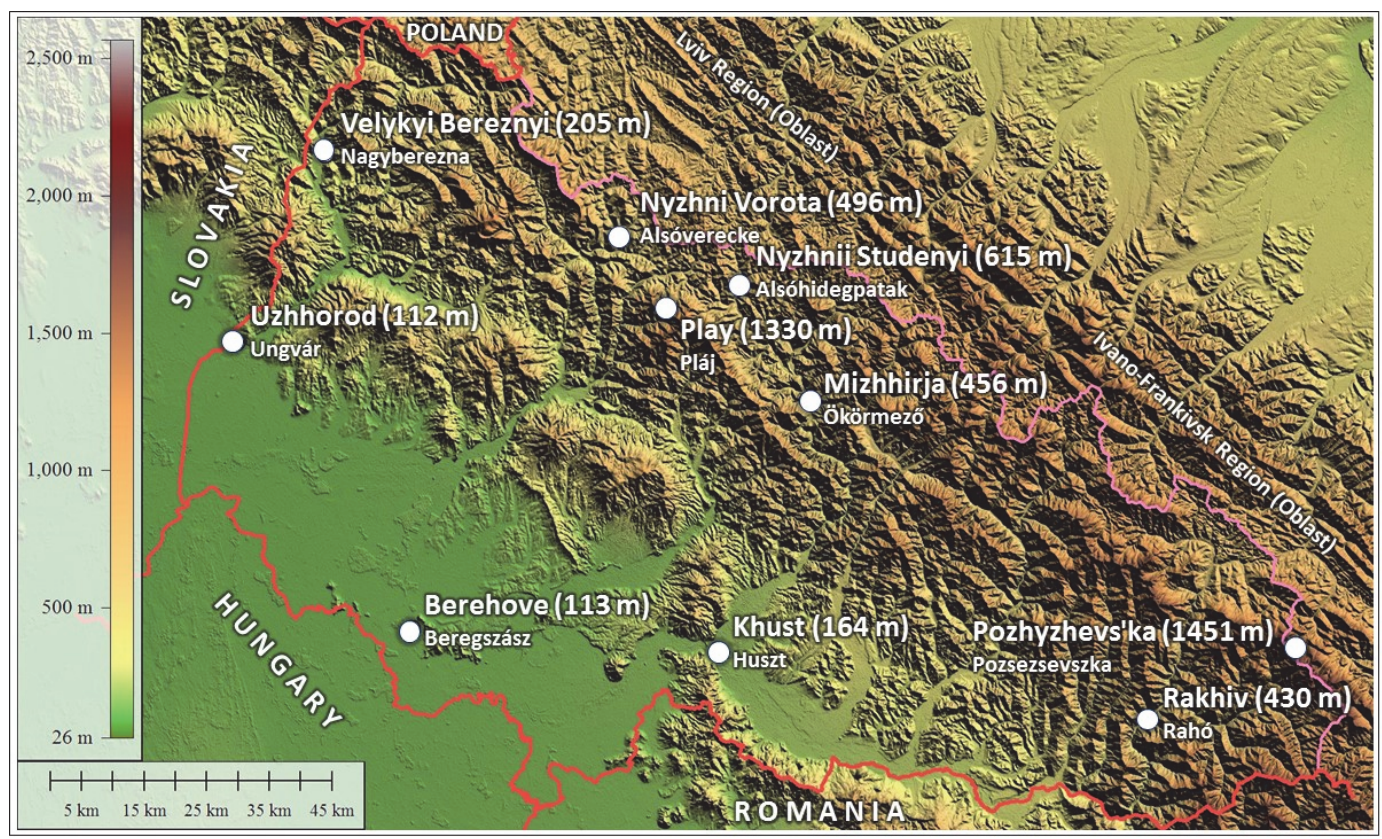

Fig. 1. Geographical locations and altitudes above sea level (m) of the meteorological stations comprising the database. 
Table 1. Exact geographical coordinates of the meteorological stations and anemometer altitudes ( $\varphi$ : latitude, $\lambda$ : longitude, h: elevation, $\mathrm{h}_{\mathrm{a}}$ : anemometer altitude above ground level)

\begin{tabular}{llcccc}
\hline \hline \multicolumn{2}{c}{ Meteorological station } & \multicolumn{2}{c}{$\begin{array}{c}\text { Geographical } \\
\text { coordinates }\end{array}$} & h (m) & $\mathbf{h}_{\mathbf{a}}(\mathbf{m})$ \\
\hline $\begin{array}{l}\text { WMO } \\
\text { index }\end{array}$ & Station name & $\begin{array}{c}\varphi \\
\text { (north) }\end{array}$ & $\begin{array}{c}\lambda \\
\text { (east) }\end{array}$ & Jan 2011. - Dec 2015. \\
\hline \hline 33631 & Uzhhorod & $48^{\circ} 38^{\prime}$ & $22^{\circ} 16^{\prime}$ & 112 & 14 \\
33634 & Berehove & $48^{\circ} 12^{\prime}$ & $22^{\circ} 39^{\prime}$ & 113 & 10 \\
33638 & Khust & $48^{\circ} 11^{\prime}$ & $23^{\circ} 18^{\prime}$ & 164 & 16 \\
33514 & Velykyi Bereznyi & $48^{\circ} 54^{\prime}$ & $22^{\circ} 28^{\prime}$ & 205 & 10 \\
33647 & Rakhiv & $48^{\circ} 03^{\prime}$ & $24^{\circ} 12^{\prime}$ & 430 & 10 \\
33633 & Mizhhirja & $48^{\circ} 31^{\prime}$ & $23^{\circ} 30^{\prime}$ & 456 & 10 \\
33517 & Nyzhni Vorota & $48^{\circ} 46^{\prime}$ & $23^{\circ} 06^{\prime}$ & 496 & 10 \\
33518 & Nyzhnii Studenyi & $48^{\circ} 42^{\prime}$ & $23^{\circ} 22^{\prime}$ & 615 & 10 \\
33515 & Play & $48^{\circ} 40^{\prime}$ & $23^{\circ} 12^{\prime}$ & 1330 & 8 \\
33646 & Pozhyzhevs'ka & $48^{\circ} 09^{\prime}$ & $24^{\circ} 32^{\prime}$ & 1451 & 11 \\
\hline
\end{tabular}

As a first step, a histogram was made from the wind speed data series, similarly to previous studies classifying wind speeds using $\Delta x=1 \mathrm{~m} / \mathrm{s}$ (Khan et al., 2014; Costa Rocha et al., 2012; Xydis, 2012; Kravchyshyn et al., 2016). Following this, several theoretical distributions were tested in order to approximate the empirical frequency distribution of wind data. The distribution densities and parameters of their determination are as follows:

- Weibull distribution. The distribution density of the Weilbull distribution can be presented simplest in the following form (Justus et al., 1978; Tar, 2008; Kartashov, 2008):

$$
f(x ; k ; c)=\frac{k}{c}\left(\frac{x}{c}\right)^{k-1} e^{-\left(\frac{x}{c}\right)^{k}} .
$$

The following three methods were applied to determine the $k$ and $c$ parameters of the distribution:

The first method is in fact a linear regression made on the transformed values of the center of speed intervals $\left(v_{i}\right)$ and the corresponding cumulated frequency $\left(p_{i}\right)$. Transformations are as follows (Şahini and Aksakal, 1999; Tar, 2008):

$$
x_{i}=\ln \left(v_{i}\right) \quad \text { and } \quad y_{i}=\ln \left[-\ln \left(1-p_{i}\right)\right] .
$$


From $y=a+b x$ the regression equation constants $c$ and $k$ can be determined in the following way:

$$
c=\exp \left(-\frac{\mathrm{a}}{\mathrm{b}}\right) \quad \text { and } \quad \mathrm{k}=\mathrm{b} \text {. }
$$

The second method is based on the lower and upper quartiles ( $q 1$ and $q 3$ ), as well as median ( $q 2)$ of wind speed. Thus, the $k$ and $c$ parameters can be determined in the following way (Tar, 2008):

$$
\begin{gathered}
k=\ln \frac{\left(\frac{\ln 0,25}{\ln 0,75}\right)}{\ln \left(\frac{q_{3}}{q_{1}}\right)}=\frac{1,573}{\ln \left(\frac{q_{3}}{q_{1}}\right)}, \\
c=\frac{q_{2}}{(\ln 2)^{\frac{1}{k}}} .
\end{gathered}
$$

The third method can be traced back to the estimation of momentum (Tar, 2008; Costa Rocha et al., 2012; Maklad and Glencross-Grant, 2014; Kravchyshyn et al., 2016). If the average wind speed $\left(v_{m}\right)$ and the standard deviation $\left(s_{n}\right)$ are known, then

$$
\begin{gathered}
k=\left(\frac{s_{n}}{v_{m}}\right)^{-1,086}, \\
c=\frac{v_{m}}{\Gamma\left(1+\frac{1}{k}\right)} .
\end{gathered}
$$

where $s_{n} / v_{m}$ is the coefficient of variation, while $\Gamma(x)$ is the gamma function.

By means of the three different methods mentioned above the Weibull parameters can be determined at the anemometer altitude. However, if we proceed from this and want to give distributions at different altitudes, then we have to use the above-mentioned characteristics of Weibull distribution, i.e., the distribution parameters for other altitudes can be calculated on the basis of the values related to the measurement level. If the value of parameters at the altitude of anemometer $z_{a}$ are $c_{a}$ and $k_{a}$, then at a $\mathrm{z} \neq z_{a}$ level (Tar, 2008; Kidmo et al., 2015):

$$
\begin{gathered}
c_{z}=c_{a}\left(\frac{z}{z_{a}}\right)^{n} \text { and } \\
k_{z}=\frac{k_{a}\left[1-0,088 \ln \left(\frac{z_{a}}{10}\right)\right]}{\left[1-0,088 \ln \left(\frac{z}{10}\right)\right]} .
\end{gathered}
$$

Exponent $n$ is: 


$$
n=\frac{\left[0,37-0,088 \ln c_{a}\right]}{\left[1-0,088 \ln \left(\frac{z_{a}}{10}\right)\right]}
$$

By working out daily average wind speed distribution at a level different from the anemometer altitude, knowing the scale- and shape parameter at this altitude, average wind speed, standard deviation, mode, and coefficient of variation can be calculated.

The average $v_{m}$ sample taken from the probability variable of the Weibull distribution can be determined in the following way (Troen and Petersen, 1989):

$$
v_{m}=c \Gamma\left(1+\frac{1}{k}\right),
$$

where $c$ and $k$ are parameters of the distribution at a given altitude.

Its standard deviation is the following (Azad et al., 2014):

$$
\sigma=c\left[\Gamma\left(1+\frac{1}{k}\right)-\Gamma^{2}\left(1+\frac{1}{k}\right)\right]^{\frac{1}{2}},
$$

and its distribution mode is characterized by Eq. (13) (Dokur and Kurban, 2015):

$$
M_{0}=c\left(1-\frac{1}{k}\right)^{\frac{1}{k}} \text {. }
$$

- Rayleigh distribution. If $k=2$, then a special case of the Weibull distribution, the distribution density of the Rayleigh distribution is obtained (Tar, 2008; Kartashov, 2008; Schönwiese, 2013). The distribution density of Rayleigh distribution can be described in the following way:

$$
f(x ; c)=\frac{2 x}{c^{2}} e^{-\left(\frac{x}{c}\right)^{2}} .
$$

The expected value of the probability variable of such a distribution is:

$$
\mu=\frac{c \sqrt{\pi}}{2},
$$

i.e., the estimated value of the $c$ parameter is proportional to the average.

- Normal distribution. The distribution function of the normal distribution is:

$$
f(x ; \mu ; c)=\frac{1}{\sigma \sqrt{2 \pi}} e^{-\frac{(x-\mu)^{2}}{2 \sigma^{2}}} .
$$


Its parameters are the $\mu$ expected value and the $\sigma$ standard deviation of the $\xi$ probability variable.

- Log-normal distribution. The distribution density of the log-normal distribution is:

$$
f(x ; \mu ; \sigma)=\frac{1}{\sigma x \sqrt{2 \pi}} e^{-\frac{(\ln x-\mu)^{2}}{2 \sigma^{2}}}
$$

Its parameters are the $\mu$ expected value and the $\sigma$ standard deviation of the $\ln \xi$ probability variable $(\xi>0)$.

- Gamma distribution. The distribution density of the gamma distribution is:

$$
\begin{array}{ll}
f(x ; \lambda ; p)=\frac{\lambda^{p}}{\Gamma(p)} x^{p-1} e^{-\lambda x}, & \text { if } x>0 \\
f(x ; \lambda ; p)=0, & \text { if } x \leq 0,
\end{array}
$$

where $\Gamma(p)$ is a gamma-function. The $\mu$ expected value and the $\sigma^{2}$ squared standard deviation of a probability variable with such a distribution are:

$$
\begin{aligned}
\mu & =\frac{p}{\lambda} \text { and } \\
\sigma^{2} & =\frac{p}{\lambda^{2}},
\end{aligned}
$$

where parameters $p$ and $\lambda$ are easy to estimate (Dévényi and Gulyás, 1988, Matyasovszky, 2002; Tar, 2008; Kravchyshyn et al., 2016).

We performed the $\chi^{2}$ goodness of fit test at significance levels of $10 \%, 5 \%$, and $1 \%$. The results are summarized in Table 2, in which the cases where the approximation proved to be good at least at one of the above significance levels are marked. Finally, having determined the linear correlation coefficient $(r)$, significant statistical relations between the altitude above sea level of the measurement point and the scale parameter of the Weibull distribution were looked for. To test our $H_{0}: \rho=0$ hypothesis with the aim of studying the significance of the connection between the two variables, the F-test used in variance analyses was applied (ANOVA). The total sum of squares (TSS) has two components: the regression sum of squares (RSS) and the error sum of squares (ESS). By means of the sum of squares determined from the samples the existence of the null hypothesis was analyzed (Huzsvai and Vincze, 2012): 


$$
F=\frac{\frac{R S S}{\rho}}{\frac{E S S}{n-\rho-1}},
$$

where the numerator's degree of freedom is $s z f_{1}=m$, and the denominator's degree of freedom is $s z f_{2}=n-\rho-1$.

\section{Results}

\subsection{Frequency distribution of wind speeds at the studied stations}

To show the assumed orographic differences, concrete distribution analyses were performed regarding the altitude of the measurement level in the case of each particular station. Histograms of wind speed, $\Delta x=1 \mathrm{~m} / \mathrm{s}$, subdivided into classes and formed on the basis of data series referring to the entire period (Fig. 2) yield a different picture at various stations according to local wind peculiarities. At the stations situated on plains or in mountainous narrow river valleys, maximum 5 (Nyzhnii Studenyi), 8 (Velykyi Bereznyi, Mizhhirja, Nyzhni Vorota), or 9 (Uzhhorod, Rakhiv) wind speed classes can be singled out. The frequency distribution of stations on high mountain ridges or near the mountain peak can be described by means of more wind speed classes, in Pozhyzhevs'ka by 17, while in Play by approximately 20 classes. Due to slow wind speed, $94.3 \%$ of the data in Berehove belong to the $0-1 \mathrm{~m} / \mathrm{s}$ class. In Khust this class includes $73.7 \%$ of the data. For this reason, approximation of the daily average wind speed at these two stations did not yield positive results (Table 2).

Table 2. Summarizing table of the empirical and theoretical distributions for the entire period, divided into seasons at various probability levels (marked with an * in the case of a significant fitting)

\begin{tabular}{|c|c|c|c|c|c|c|c|c|c|c|c|c|c|c|c|c|c|c|c|}
\hline \multirow{2}{*}{$\begin{array}{c}\begin{array}{c}\text { Distribution- } \\
\text { type }\end{array} \\
\text { Significance } \\
\text { level (\%) } \\
\end{array}$} & \multirow{2}{*}{ 芯 } & \multicolumn{3}{|c|}{$\begin{array}{c}\text { Weibull } \\
1^{\text {st }} \\
\text { method }\end{array}$} & \multicolumn{3}{|c|}{$\begin{array}{c}\text { Weibull } \\
2^{\text {nd }} \\
\text { method }\end{array}$} & \multicolumn{3}{|c|}{$\begin{array}{c}\text { Weibull } \\
3^{\text {rd }} \\
\text { method }\end{array}$} & \multicolumn{3}{|c|}{ Normal } & \multicolumn{3}{|c|}{$\begin{array}{c}\text { Log- } \\
\text { normal }\end{array}$} & \multicolumn{3}{|c|}{ Gamma } \\
\hline & & 10 & 5 & 1 & 10 & 5 & 1 & 10 & 5 & 1 & 10 & 5 & 1 & 10 & 5 & 1 & 10 & 5 & 1 \\
\hline \multirow{5}{*}{$\begin{array}{l}\text { Uzhhorod } \\
(112 \mathrm{~m})\end{array}$} & entire & & & & $*$ & * & * & $*$ & $*$ & $*$ & & & & & & & & & \\
\hline & winter & & & & * & * & * & $*$ & $*$ & $*$ & & & & & & & & & \\
\hline & spring & & & & & & & $*$ & $*$ & $*$ & & & & & & & & & \\
\hline & summer & & & & & & & $*$ & $*$ & $*$ & & & & & & & & & \\
\hline & autumn & & & & $*$ & $*$ & * & $*$ & $*$ & $*$ & & & & & & & & & \\
\hline $\begin{array}{l}\text { Berehove } \\
(113 \mathrm{~m})\end{array}$ & $\begin{array}{c}\text { entire } \\
\text { winter } \\
\text { spring } \\
\text { summer } \\
\text { autumn }\end{array}$ & & & & & & & & & & & & & & & & & & \\
\hline
\end{tabular}


Table 2. Continue

\begin{tabular}{|c|c|c|c|c|c|c|c|c|c|c|c|c|c|c|c|c|c|c|c|}
\hline \multirow{2}{*}{$\begin{array}{c}\begin{array}{c}\text { Distribution- } \\
\text { type }\end{array} \\
\text { Significance } \\
\text { level }(\%) \\
\end{array}$} & \multirow{2}{*}{ 国 } & \multicolumn{3}{|c|}{$\begin{array}{c}\text { Weibull } \\
\text { 1st } \\
\text { method }\end{array}$} & \multicolumn{3}{|c|}{$\begin{array}{l}\text { Weibull } \\
\text { 2nd } \\
\text { method }\end{array}$} & \multicolumn{3}{|c|}{$\begin{array}{c}\text { Weibull } \\
\text { 3rd } \\
\text { method }\end{array}$} & \multicolumn{3}{|c|}{ Normal } & \multicolumn{3}{|c|}{$\begin{array}{c}\text { Log- } \\
\text { normal }\end{array}$} & \multicolumn{3}{|c|}{ Gamma } \\
\hline & & 10 & 5 & 1 & 10 & 5 & 1 & 10 & 5 & 1 & 10 & 5 & 1 & 10 & 5 & 1 & 10 & 5 & 1 \\
\hline $\begin{array}{l}\text { Khust } \\
(164 \mathrm{~m})\end{array}$ & $\begin{array}{l}\text { entire } \\
\text { winter } \\
\text { spring } \\
\text { summer } \\
\text { autumn }\end{array}$ & & & & & & & & & & & & & & & & & & \\
\hline \multirow{5}{*}{$\begin{array}{l}\text { Velykyi } \\
\text { Bereznyi } \\
(205 \mathrm{~m})\end{array}$} & entire & & & & $*$ & $*$ & $*$ & $*$ & $*$ & $*$ & & & & & & & & & \\
\hline & winter & & & & $*$ & $*$ & $*$ & $*$ & $*$ & $*$ & & & & & & & $*$ & $*$ & $*$ \\
\hline & spring & & & & & & & $*$ & $*$ & $*$ & & & & & & & & & \\
\hline & summer & & & & & & & $*$ & $*$ & $*$ & & & & & & & & & \\
\hline & autumn & & & & $*$ & $*$ & $*$ & $*$ & $*$ & $*$ & & & & & & & $*$ & $*$ & $*$ \\
\hline \multirow{5}{*}{$\begin{array}{l}\text { Rakhiv } \\
(430 \mathrm{~m})\end{array}$} & entire & & & & & & & $*$ & $*$ & $*$ & & & & & & & $*$ & * & $*$ \\
\hline & winter & & & & $*$ & $*$ & $*$ & $*$ & $*$ & * & & & & & & & & & \\
\hline & spring & & & & & & & $*$ & $*$ & $*$ & & & & & & & & & \\
\hline & summer & & & & & & & $*$ & $*$ & $*$ & & & & & & & & & \\
\hline & autumn & & & & & & $*$ & $*$ & $*$ & $*$ & & & & & & & & & \\
\hline \multirow{5}{*}{$\begin{array}{l}\text { Mizhhirja } \\
(456 \mathrm{~m})\end{array}$} & entire & & & & $*$ & $*$ & $*$ & $*$ & $*$ & $*$ & & & & & & & & & \\
\hline & winter & & & & & & & $*$ & $*$ & $*$ & & & & & & & & & \\
\hline & spring & & & & & & & $*$ & $*$ & $*$ & & & & & & & & & \\
\hline & summer & & & & $*$ & $*$ & $*$ & $*$ & $*$ & $*$ & & & & & & & & & \\
\hline & autumn & & & & & & & $*$ & $*$ & $*$ & & & & & & & & & \\
\hline \multirow{5}{*}{$\begin{array}{l}\text { Nyzhni } \\
\text { Vorota } \\
(496 \mathrm{~m})\end{array}$} & entire & & & & & $*$ & $*$ & $*$ & $*$ & $*$ & & & & & & & & & \\
\hline & winter & $*$ & $*$ & $*$ & $*$ & $*$ & $*$ & $*$ & $*$ & $*$ & & & & & & & & & \\
\hline & spring & & & & & & & $*$ & $*$ & $*$ & & & & & & & & & \\
\hline & summer & & & & $*$ & $*$ & $*$ & $*$ & $*$ & $*$ & & & & & & & & & \\
\hline & autumn & & & & $*$ & $*$ & $*$ & $*$ & $*$ & $*$ & & & & & & & & & \\
\hline \multirow{4}{*}{$\begin{array}{l}\text { Nyzhnii } \\
\text { Studenyi } \\
(615 \mathrm{~m})\end{array}$} & entire & & & & & & & $*$ & * & $*$ & & & & & & & & & \\
\hline & winter & & & & $*$ & $*$ & $*$ & $*$ & $*$ & $*$ & $*$ & $*$ & $*$ & & & & & & \\
\hline & spring & & & & & & & & & & & & & & & & & & \\
\hline & $\begin{array}{l}\text { summer } \\
\text { autumn }\end{array}$ & & & & $*$ & $*$ & $*$ & $*$ & $*$ & $*$ & & & & & & & & & \\
\hline \multirow{5}{*}{$\begin{array}{c}\text { Play } \\
(1330 \mathrm{~m})\end{array}$} & entire & & & & $*$ & * & $*$ & $*$ & * & $*$ & & & & & & & & & \\
\hline & winter & & & & $*$ & * & $*$ & $*$ & $*$ & $*$ & & & & & & & & & \\
\hline & spring & & & & $*$ & $*$ & $*$ & $*$ & $*$ & $*$ & & & & & & & & & \\
\hline & summer & & & & $*$ & $*$ & $*$ & $*$ & $*$ & $*$ & & & & & & & & & \\
\hline & autumn & & & & $*$ & $*$ & $*$ & $*$ & $*$ & $*$ & $*$ & $*$ & $*$ & & & & & & \\
\hline \multirow{5}{*}{$\begin{array}{l}\text { Pozhyzhevs'ka } \\
\text { (1451 m) }\end{array}$} & entire & & & & $*$ & $*$ & $*$ & $*$ & $*$ & $*$ & & & & & & & $*$ & $*$ & $*$ \\
\hline & winter & & & & $*$ & $*$ & $*$ & $*$ & $*$ & $*$ & & & & & & & $*$ & $*$ & $*$ \\
\hline & spring & * & $*$ & $*$ & * & $*$ & $*$ & * & $*$ & $*$ & & & & & & & $*$ & $*$ & $*$ \\
\hline & summer & & & & $*$ & $*$ & $*$ & $*$ & $*$ & $*$ & & & & & & & & & \\
\hline & autumn & $*$ & $*$ & $*$ & $*$ & $*$ & $*$ & $*$ & $*$ & $*$ & & & & & & & $*$ & $*$ & $*$ \\
\hline
\end{tabular}




\subsection{Analysis of the shape- and scale parameter of Weibull distribution}

Table 2 shows that in most cases, the Weibull distribution offers the best approximation among the empirical frequency distribution of daily average wind speed time series. The two input parameters of the Weibull distribution, as it has already been mentioned above, can be determined by numerous methods, see Eqs. (2)-(7). The three selected methods resulted different parameter values. Therefore, the fittings were not the same. Among the three-parameter determining methods, the third method was proved to be the best at Transcarpathian stations, therefore we analyze its results.

In the entire period, the value of the $k$ parameter (Table 3) varied from station to station: 0.64 in Berehove and 2.71 in Khust. However, the data series of these two stations could not be approximated by Weibull distribution. In the case of the rest of the stations, the $k$ value varied from 1.0 in Rakhiv to 2.19 in Nyzhnii Studenyi. With reference to the whole observation plot, the oscillation makes up 2.07. When divided into seasons, the $k$ value seems to be different at different stations. Highest values are found in spring (Berehove, Mizhhirja) and in summer (Uzhhorod, Khust, Velykyi Bereznyi, Rakhiv, Nyzhni Vorota, Nyzhnii Studenyi, Play, and Pozhyzhevs'ka). When compared, the highest seasonal values also show significant deviation; the difference between 3.95 in Khust and 0.70 in Berehove is 3.25.

Table 3. Values of $(k)$ the shape parameter (a dimensionless number) subdivided into the whole studied period and into seasons (italics - a value showing no significant fitting, but offering the best approximation; bold - the highest value)

\begin{tabular}{|c|c|c|c|c|c|c|c|c|c|c|}
\hline & 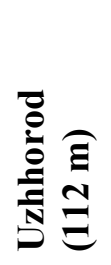 & 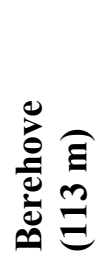 & 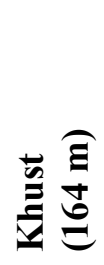 & 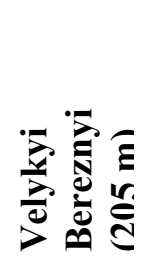 & 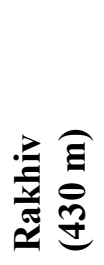 & 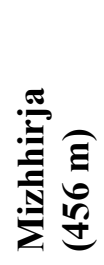 & 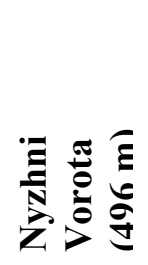 & 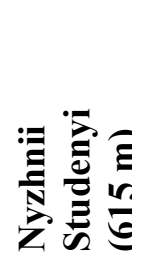 & 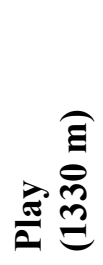 & 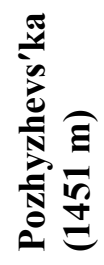 \\
\hline entire & 1.82 & 0.64 & 2.71 & 1.32 & 1.0 & 1.48 & 1.59 & 2.19 & 1.65 & 1.15 \\
\hline winter & 1.68 & 0.65 & 2.24 & 1.21 & 0.79 & 1.43 & 1.56 & 2.07 & 1.65 & 1.18 \\
\hline spring & 2.12 & 0.70 & 2.79 & 1.50 & 1.36 & 1.84 & 1.82 & 2.64 & 1.76 & 1.23 \\
\hline summer & 2.20 & 0.64 & 3.95 & 1.78 & 1.38 & 1.79 & 2.04 & 2.66 & 1.81 & 1.44 \\
\hline autumn & 1.61 & 0.23 & 2.74 & 1.13 & 0.87 & 1.31 & 1.46 & 2.04 & 1.58 & 1.17 \\
\hline
\end{tabular}


Where the average wind speed is the highest and the shape parameter of Weibull distribution is the lowest, the specific wind power is the greatest (Henessey, 1977). In Transcarpathia, the $k$ values are relatively low, they are not combined with significant average wind speed (Table 5), thus the specific wind power is surely not high except for the Play station. High $k$ values can mean low variability of the wind power.

With reference to the whole period, the value of the $c$ parameter (Table 4) shows greater variability at different stations. For a five-year-long period the value was $5 \mathrm{~m} / \mathrm{s}$. The highest value was found at Play station (5.23), while the lowest one was detected at Berehove station (0.23). The occurrence of the two extremes was expected for the scale parameter values closely followed the average wind speed values of the stations (Table 5). Side by side with the spread, the standard deviation values support the differences arising from the wind at two measurement points, since at Berehove station the standard deviation value is 0.38 $\mathrm{m} / \mathrm{s}$, while at Play station it is 0.66 . At Pozhyzhevs'ka station the standard deviation is $0.82 \mathrm{~m} / \mathrm{s}$, however, it is not here that the $c$ value is the highest as the average wind speed is not the highest here, only the standard deviation of data is significant. This indicates that wind differs in various parts of the observation plot.

Table 4. Values of the scale parameter $c(\mathrm{~m} / \mathrm{s})$ subdivided into the whole studied period and into seasons (italics - a value showing no significant fitting, but offering the best approximation; bold - the highest value)

\begin{tabular}{|c|c|c|c|c|c|c|c|c|c|c|}
\hline ت & 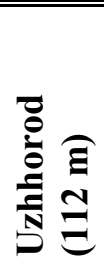 & 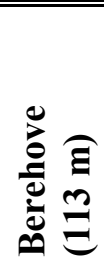 & 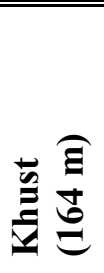 & 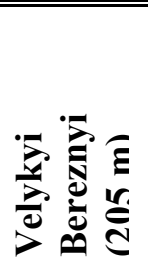 & 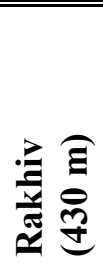 & 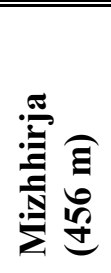 & 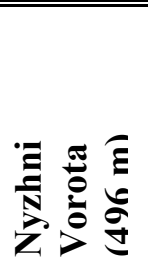 & 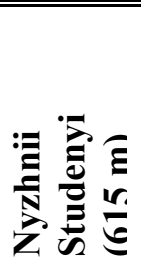 & 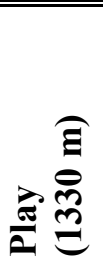 & 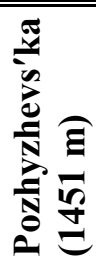 \\
\hline entire & 2.30 & 0.23 & 1.03 & 1.42 & 1.44 & 1.30 & 2.02 & 1.66 & 5.23 & 3.59 \\
\hline winter & 2.25 & 0.24 & 0.94 & 1.30 & 1.22 & 1.47 & 2.40 & 1.93 & 5.91 & 4.73 \\
\hline spring & 2.82 & 0.35 & 1.18 & 1.92 & 2.15 & 1.66 & 2.32 & 1.76 & 5.54 & 3.47 \\
\hline summer & 2.21 & 0.18 & 1.03 & 1.43 & 1.31 & 0.86 & 1.71 & 1.44 & 4.36 & 2.74 \\
\hline autumn & 1.92 & 0.00 & 0.95 & 1.02 & 1.12 & 1.03 & 1.69 & 1.50 & 5.16 & 3.65 \\
\hline
\end{tabular}

The maximum value of the $c$ parameter at stations in Uzhhorod, Berehove, Khust, Velykyi Bereznyi, Rakhiv, and Mizhhirja occurs in spring, while at Nyzhni Vorota, Nyzhnii Studenyi, Play, and Pozhyzhevs'ka stations it occurs in winter. This can be explained by that the primary wind maximum at the stations is generally observed at this time of the year. 


\subsection{Frequency distribution of the daily average wind speed at $80 \mathrm{~m}$ above ground level}

By means of the Weibull distribution parameters, the distribution density function, some of its statistical parameters, the average value of the probability variable, its standard deviation, mode, and coefficient of variation were worked out at an altitude $z=80 \mathrm{~m}$ differing from the anemometer altitude $\left(z_{a}\right)$. There is a significant fitting between the stations in Tables 3 and 4, in Berehove and Khust. Significant fitting was not used, but the parameters determined using the third Weibull method that showed the best approximation was applied. First of all, by means of Eqs. (8), (9), and (10) the $n$ exponent, then the $c_{z}$ and $k_{z}$ parameters were determined. The obtained distribution at $z=80 \mathrm{~m}$ is presented in Fig. 2.

By comparing the statistical parameters of wind conditions at two levels, the average values of wind speed at 10 measurement stations in the period between 2011 and 2015 at anemometer altitude vary between $0.32 \mathrm{~m} / \mathrm{s}$ in Berehove and 4.68 in Play. Average wind speed at stations does not exceed $3 \mathrm{~m} / \mathrm{s}$ except for Play and Pozhyzhevs'ka $(3.41 \mathrm{~m} / \mathrm{s})$, as they have higher altitude above sea level. The same spatial distribution can be observed, however, with higher values regarding the $80 \mathrm{~m}$ level at the stations, i.e., Berehove has the lowest $(0.74 \mathrm{~m} / \mathrm{s})$, while the station at Play has the highest $(7.32 \mathrm{~m} / \mathrm{s})$ average value. Among the stations not situated in highlands or on mountain ridges, Uzhhorod and Nyzhni Vorota could be highlighted where average wind speed at $80 \mathrm{~m}$ reaches $3.85 \mathrm{~m} / \mathrm{s}$ and $3.40 \mathrm{~m} / \mathrm{s}$, respectively. Regarding the most frequent value in the data series, i.e., the mode, again the station at Play had the maximum value $(2.13 \mathrm{~m} / \mathrm{s})$. Conversely, in Pozhyzhevs'ka, which is also situated in a highland, the mode value is $0.50 \mathrm{~m} / \mathrm{s}$ compared to the relatively high average $(3.41 \mathrm{~m} / \mathrm{s})$. This is likely to be caused by the fact that side by side with predominantly low wind speeds and longer windless periods at the station, there are wind storms with wind speeds exceeding $15 \mathrm{~m} / \mathrm{s}$ (Lavnyi and Lässig, 2009) as well. The mode of wind speed values in Pozhyzhevs'ka at $80 \mathrm{~m}$ is only $2.51 \mathrm{~m} / \mathrm{s}$. Higher values at $80 \mathrm{~m}$ can be detected at the stations in Nyzhnii Studenyi $(2.74 \mathrm{~m} / \mathrm{s})$, Uzhhorod $(3.26 \mathrm{~m} / \mathrm{s})$, and Play $(5.98 \mathrm{~m} / \mathrm{s})$. Having analyzed the coefficient of variation as the index-number of dispersion, it can be stated that the most changeable station with reference to wind at both levels is Berehove (1.50 and 1.30), while the least changeable is Khust ( 0.40 and 0.34 ). However, these two stations have the lowest average wind speed. Uzhhorod (0.49) and Play (0.51) stations are interesting as at both studied altitudes compared to other measurement points, low coefficient of variation accompanies a relatively higher average and mode, thus the occurrence of higher wind speed is more balanced, wind is more even, which is favorable from wind energy utilization point of view.

Analyzing the frequency distributions of the daily average wind speed of stations it was observed, that with wind turbines, the cumulated frequency $\left(v_{\text {mean }} \geq 3 \mathrm{~m} / \mathrm{s}(\%)\right)$ of starting $(3 \mathrm{~m} / \mathrm{s})$ and stronger wind speeds at anemometer 
altitude remained below $10 \%$ at half of the stations. However, at the altitude of 80 $\mathrm{m}$ it exceeds 50\%: at Nyzhni Vorota (53.8\%), Uzhhorod (63.9\%), Pozhyzhevs'ka $(65.1 \%)$, and Play $(83.2 \%)$.

Table 5. Weibull distribution parameters and basic statistics describing daily average wind speed distribution at anemometer $\left(z_{a}\right)$ altitude and at $80 \mathrm{~m}$ above ground level in the period between 2011 and 2015

\begin{tabular}{|c|c|c|c|c|c|c|c|c|c|c|c|}
\hline \multirow{2}{*}{ 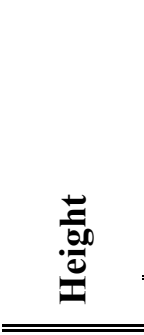 } & \multirow{2}{*}{ 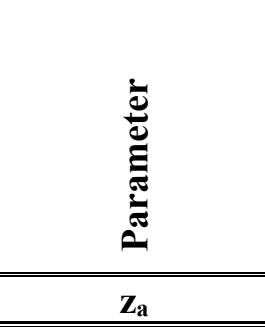 } & \multirow{2}{*}{ 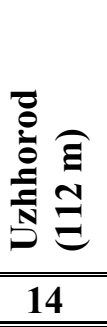 } & \multirow{2}{*}{ 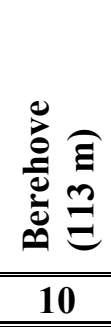 } & \multirow{2}{*}{ 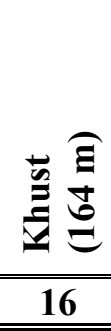 } & \multicolumn{2}{|c|}{ 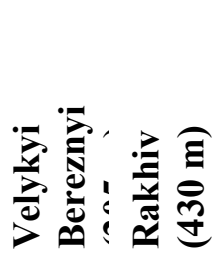 } & \multirow{2}{*}{ 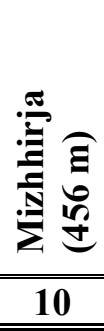 } & \multirow[t]{2}{*}{ 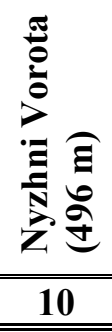 } & \multirow{2}{*}{ 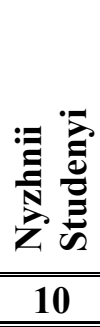 } & \multirow{2}{*}{ 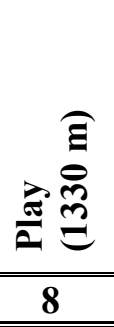 } & \multirow[t]{2}{*}{ 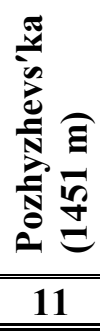 } \\
\hline & & & & & 10 & 10 & & & & & \\
\hline \multirow{7}{*}{$\mathrm{z}_{\mathrm{a}} \mathrm{m}$} & $\mathrm{k}_{\mathrm{a}}$ & 1.82 & 0.64 & 2.71 & 1.32 & 1.0 & 1.48 & 1.59 & 2.19 & 1.65 & 1.15 \\
\hline & $\mathrm{c}_{\mathrm{a}}(\mathrm{m} / \mathrm{s})$ & 2.30 & 0.23 & 1.03 & 1.42 & 1.44 & 1.30 & 2.02 & 1.66 & 5.23 & 3.59 \\
\hline & mean $(\mathrm{m} / \mathrm{s})$ & 2.05 & 0.32 & 0.92 & 1.30 & 1.44 & 1.18 & 1.82 & 1.47 & 4.68 & 3.41 \\
\hline & st. dev. (m/s) & 1.18 & 0.48 & 0.37 & 1.01 & 1.44 & 0.82 & 1.18 & 0.71 & 2.96 & 2.99 \\
\hline & $\operatorname{mode}(\mathrm{m} / \mathrm{s})$ & 1.13 & 0.00 & 0.88 & 0.75 & 0.75 & 1.00 & 1.01 & 1.25 & 2.13 & 0.50 \\
\hline & var. coeff. & 0.58 & 1.50 & 0.40 & 0.80 & 1.00 & 0.70 & 0.65 & 0.49 & 0.63 & 0.88 \\
\hline & $\mathrm{v}_{\text {mean }} \geq 3 \mathrm{~m} / \mathrm{s}(\%)$ & 17.8 & 0.5 & 0.1 & 6.3 & 12.5 & 2.4 & 14.0 & 2.6 & 62.5 & 42.6 \\
\hline \multirow{7}{*}{$\mathrm{z}=80 \mathrm{~m}$} & $\mathrm{k}_{\mathrm{z}}$ & 2.16 & 0.78 & 3.18 & 1.61 & 1.23 & 1.82 & 1.95 & 2.68 & 2.06 & 1.40 \\
\hline & $\mathrm{c}_{\mathrm{z}}(\mathrm{m} / \mathrm{s})$ & 4.35 & 0.64 & 2.29 & 2.87 & 2.91 & 2.68 & 3.84 & 3.26 & 8.27 & 6.15 \\
\hline & mean $(\mathrm{m} / \mathrm{s})$ & 3.85 & 0.74 & 2.05 & 2.57 & 2.72 & 2.38 & 3.40 & 2.90 & 7.32 & 5.61 \\
\hline & st. dev. $(\mathrm{m} / \mathrm{s})$ & 1.88 & 0.96 & 0.71 & 1.63 & 2.23 & 1.36 & 1.82 & 1.17 & 3.74 & 4.06 \\
\hline & $\operatorname{mode}(\mathrm{m} / \mathrm{s})$ & 3.26 & 0.00 & 2.03 & 1.57 & 0.73 & 1.73 & 2.65 & 2.74 & 5.98 & 2.51 \\
\hline & var. coeff. & 0.49 & 1.30 & 0.34 & 0.64 & 0.82 & 0.57 & 0.54 & 0.40 & 0.51 & 0.72 \\
\hline & $\mathrm{v}_{\text {mean }} \geq 3 \mathrm{~m} / \mathrm{s}(\%)$ & 63.9 & 3.4 & 7.5 & 33.8 & 35.0 & 28.9 & 53.8 & 44.9 & 83.2 & 65.1 \\
\hline
\end{tabular}

In wind energy examinations, the vertical wind profile is often determined by means of the so-called Hellmann's power law (Patay, 2003):

$$
\frac{v_{z}}{v_{a}}=\left(\frac{z}{z_{a}}\right)^{\alpha},
$$


where $v_{z}$ is $z$, while $v_{a}$ is the average wind speed, $z_{a}$ is measured at anemometer altitude, exponent $\alpha$ depends on the surface raggedness and the stability of the air; it changes, according to the latter, in time (e.g., daily) (Tar, 2008). Long-term, two-level wind speed measurements are necessary to determine it; however, the stations under analysis do not have them. Thus, without knowing the value of $\alpha$, the Hellmann-equation cannot be applied. However, scale $c$ parameter according to Eq. (7), is proportionate to average wind speeds, therefore, Eq. (8) can be interpreted as a kind of approximation of Hellmann-equation, where exponent $\alpha$ is given by Eq. (10).

Thus, only this exponent can be taken into account while applying Hellmannequation, i.e., the results would most probably coincide with those of Weibull distribution (exponent $n$, Table 6).

Table 6. Values of exponent $n$ at the studied stations for the entire period and per season

\begin{tabular}{|c|c|c|c|c|c|c|c|c|c|c|}
\hline 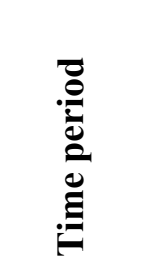 & 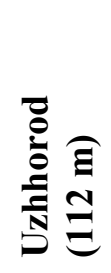 & 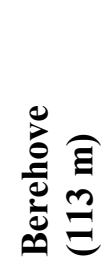 & 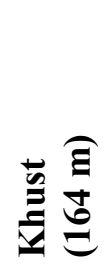 & 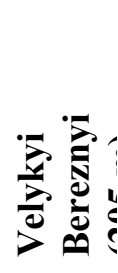 & 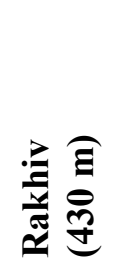 & 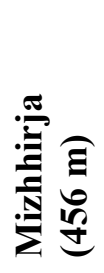 & 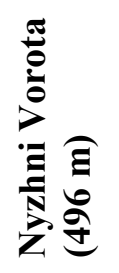 & 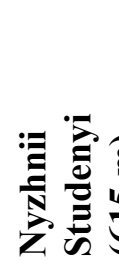 & 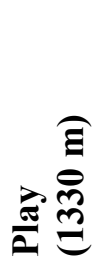 & 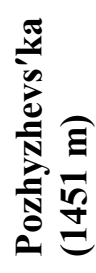 \\
\hline entire & 0.31 & 0.50 & 0.38 & 0.34 & 0.34 & 0.35 & 0.31 & 0.33 & 0.22 & 0.26 \\
\hline winter & 0.30 & 0.50 & 0.38 & 0.35 & 0.35 & 0.34 & 0.29 & 0.31 & 0.21 & 0.23 \\
\hline spring & 0.28 & 0.46 & 0.36 & 0.31 & 0.30 & 0.33 & 0.30 & 0.32 & 0.22 & 0.26 \\
\hline summer & 0.30 & 0.52 & 0.37 & 0.34 & 0.35 & 0.36 & 0.32 & 0.34 & 0.24 & 0.28 \\
\hline autumn & 0.31 & 0.52 & 0.37 & 0.37 & 0.36 & 0.37 & 0.32 & 0.33 & 0.23 & 0.26 \\
\hline
\end{tabular}




\section{Uzhhorod}
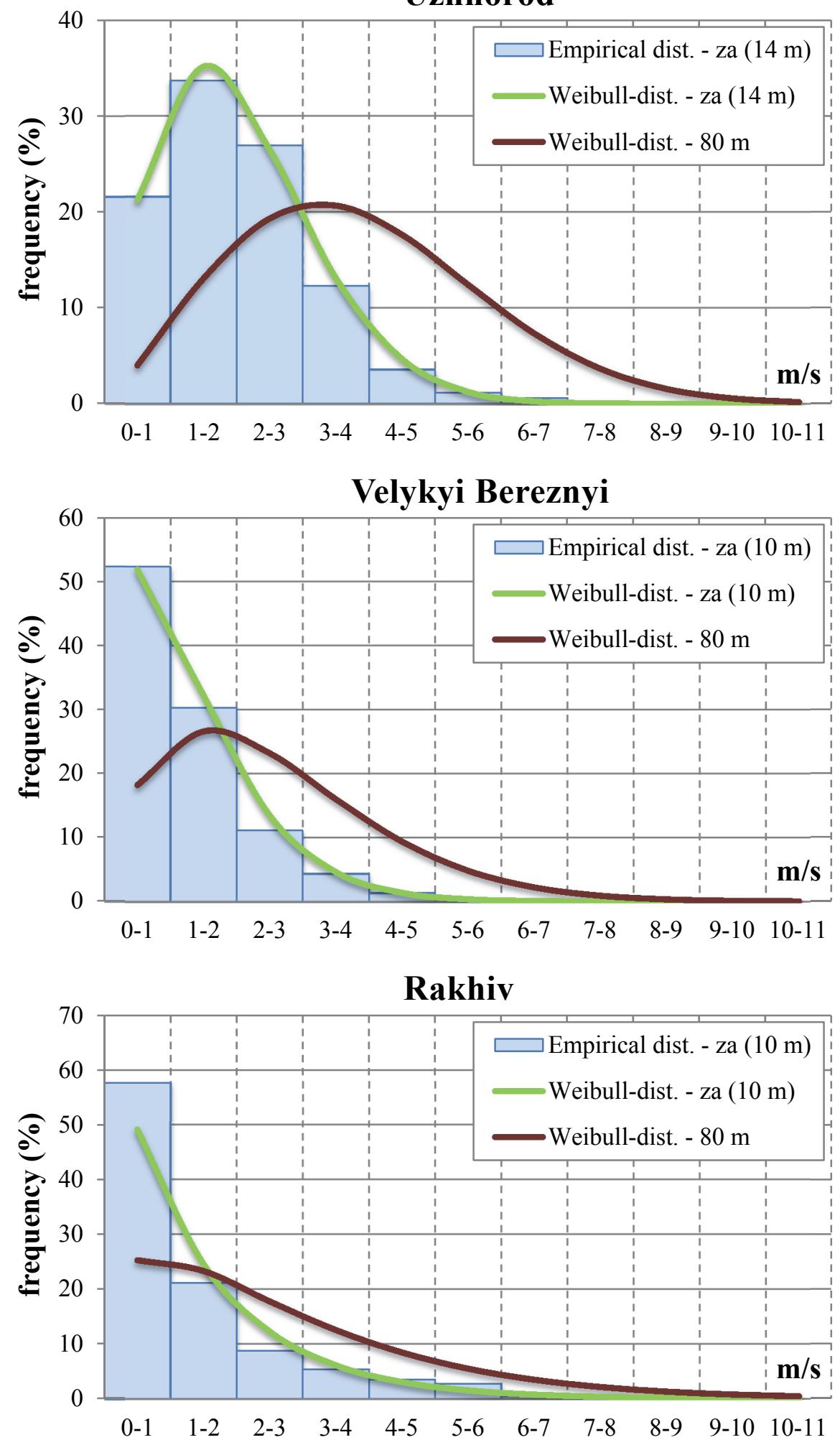

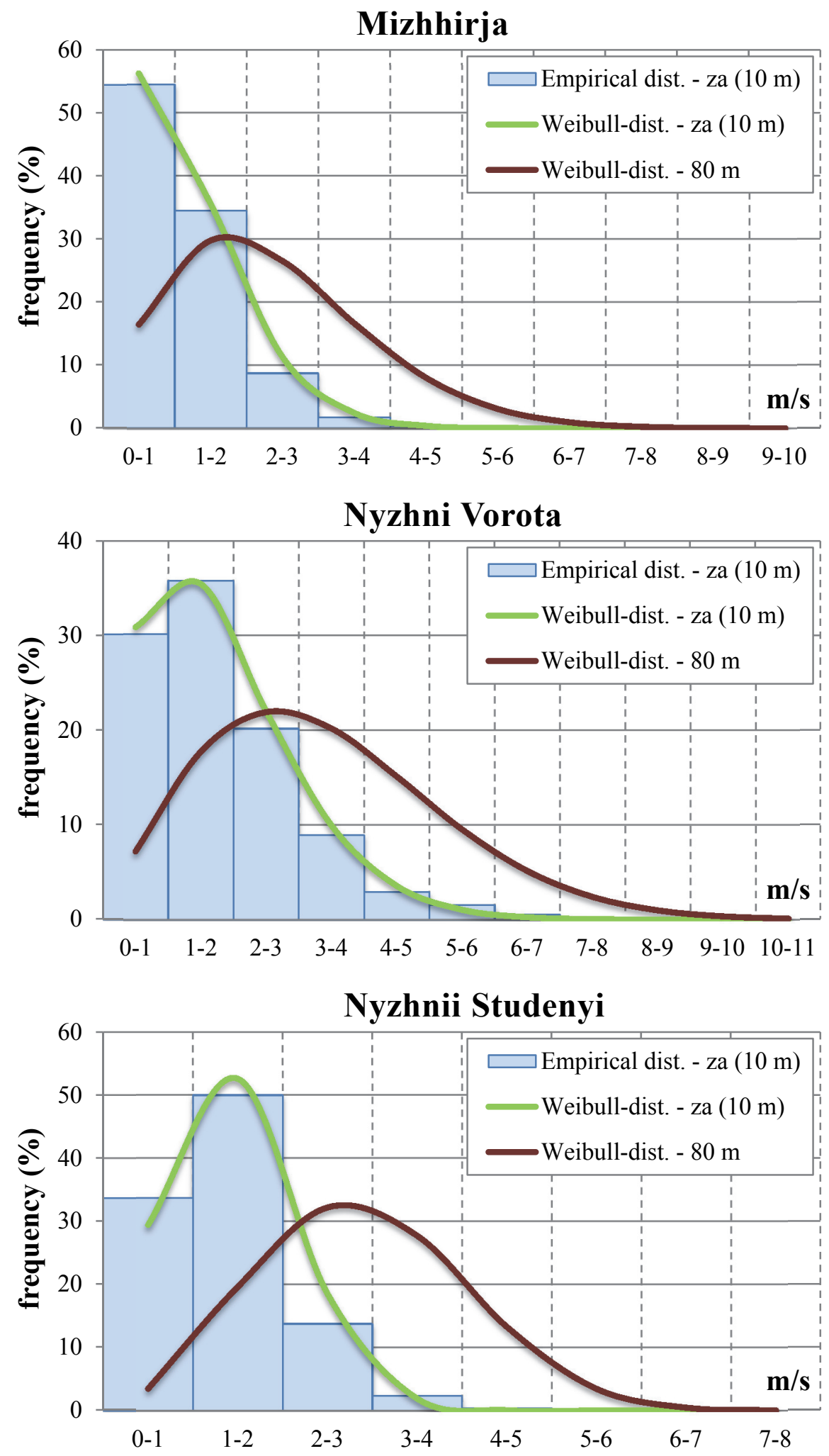

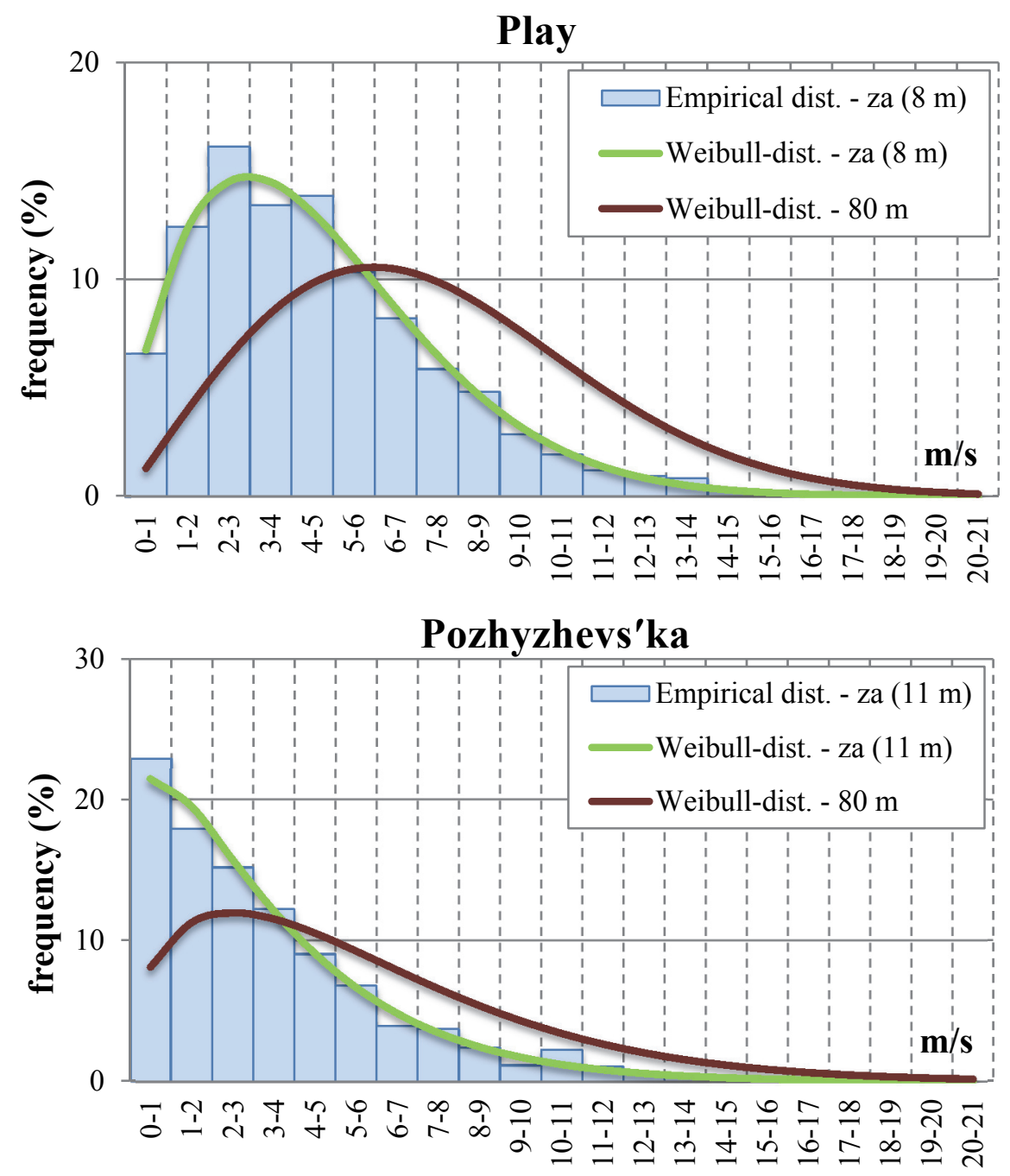

Fig. 2. Distribution of daily average wind speeds at each of the stations at anemometer altitude $\left(z_{a}\right)$ and at $80 \mathrm{~m}$ above ground level in the period between 2011 and 2015.

\subsection{Analysis of the relationship between the altitude above sea level of the measurement points and the Weibull distribution scale parameter}

The scale parameter values of Transcarpathian measurement stations are compared with their altitude above sea level. In Table 7 the $c$ values and correlation coefficients of the three parameters obtained by means of the determining method are summarised.

It seems clear that at the same station the values vary in all the three cases; values determined by means of the first method (Eqs. (2) and (3)) show the greatest difference compared to the other two. The average of absolute differences of the values obtained by means of the second (Eqs. (4) and (5)) and third (Eqs. (6) and (7)) method make up $0.02 \mathrm{~m} / \mathrm{s}$, comprising minimal deviation. 
Table 7. Comparison of scale parameters $c(\mathrm{~m} / \mathrm{s})$ of the measurement stations with altitude above sea level (m)

\begin{tabular}{lcccc}
\hline \hline Measuring point & Altitude & $\mathbf{c}_{\text {w1. medhod }}$ & $\mathbf{c}_{\mathbf{w} 2 \text {. method }}$ & $\mathbf{c}_{\mathbf{w} 3 \text {. method }}$ \\
\hline \hline Uzhhorod & 112 & 9.82 & 2.31 & 2.30 \\
Berehove & 113 & 10.57 & 0.53 & 0.23 \\
Khust & 164 & 12.58 & 0.96 & 1.03 \\
Velykyi Bereznyi & 205 & 25.78 & 1.30 & 1.42 \\
Rakhiv & 430 & 13.97 & 1.34 & 1.44 \\
Mizhhirja & 456 & 11.41 & 1.29 & 1.30 \\
Nyzhni Vorota & 496 & 9.72 & 1.86 & 2.02 \\
Nyzhnii Studenyi & 615 & 5.43 & 1.57 & 1.66 \\
Play & 1330 & 3.56 & 5.19 & 5.23 \\
Pozhyzhevs'ka & 1451 & 8.54 & 3.63 & 3.59 \\
\hline \multicolumn{2}{c}{ Correlation coefficient (r) } & -0.524 & 0.856 & 0.850 \\
\hline
\end{tabular}

Fig. 3 shows that by analyzing the linear correlation between the scale parameter, determined by Eqs. (6) and (7) yielding fitting in most cases and the altitude above sea level, significant connection is found at $95 \%$ probability level between the two variables.

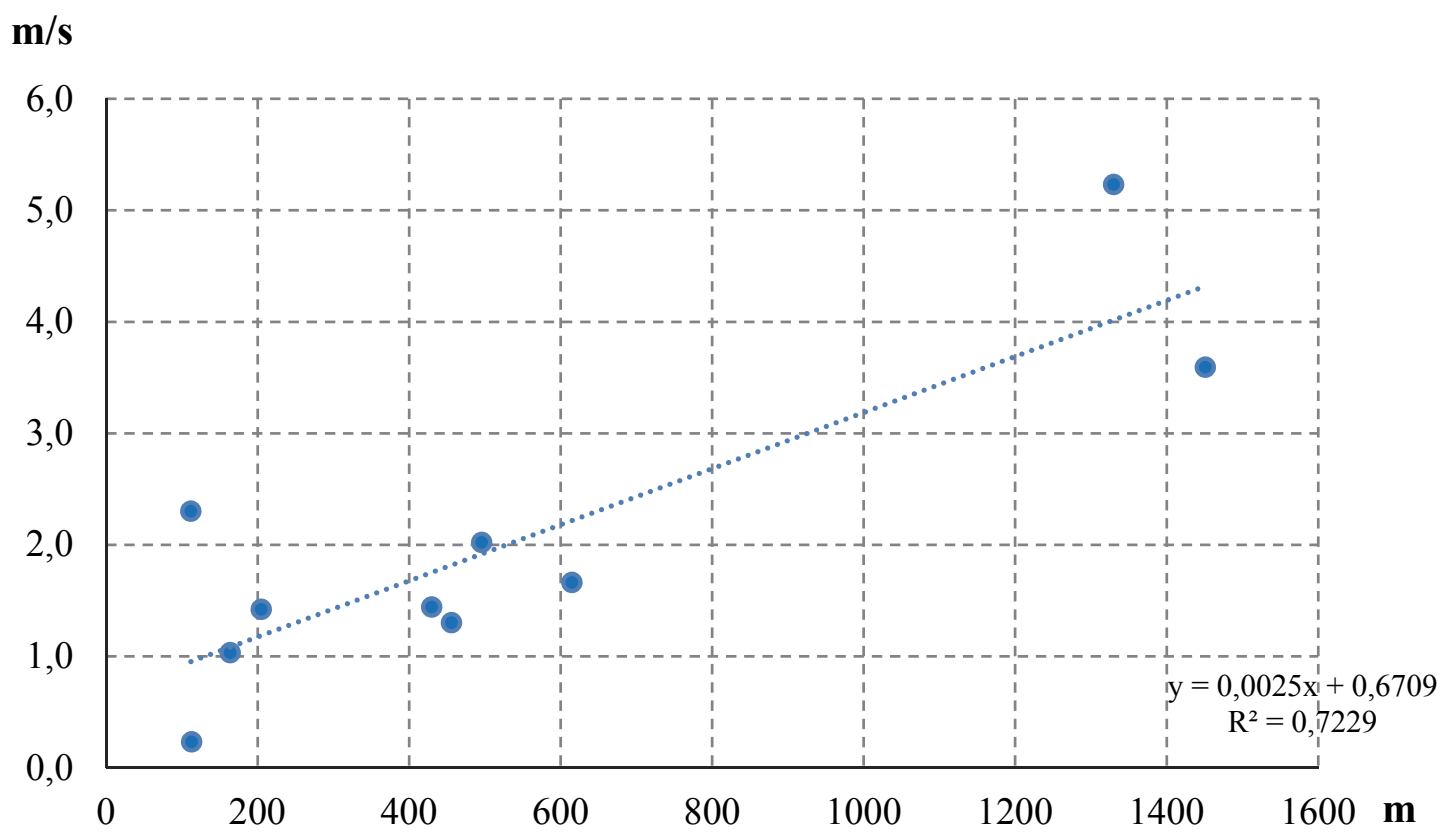

Fig. 3. Relationship between the altitude above sea level and the scale parameter. 


\section{Conclusions}

- The frequency distribution of time series related to the daily average speed of the whole period between 2011 and 2015, irrespective of the orographic environment, can easily be approximated by Weibull distribution. Berehove and Khust stations are exceptions, for no distribution yielded appropriate fitting at any chosen significance level.

- However, fitting of the Weibull distribution depends on the methods of determining the $k$ and $c$ parameters. At 8 out of 10 stations (76\% of cases) the best fittings were obtained on the basis of parameters of Eqs. (6) and (7).

- The Weibull parameters determined according to Eqs. (4) and (5) yielded positive fitting in most cases at the significance level of at least $5 \%$. The Weibull distribution parameters calculated in accordance with Eqs. (2) and (3) yielded good fitting only in some seasons at Nyzhni Vorota and Pozhyzhevs'ka stations. Similarly, gamma distribution could only be applied in Velykyi Bereznyi, Rakhiv, and Pozhyzhevs'ka stations in the entire period or in a particular season; normal distribution proved to be good in two cases. Log-normal distribution and a special case of Weibull distribution making it easier to determine parameters, while the Rayleigh distribution cannot be applied for the daily average wind speed time series of the Transcarpathian measurement stations.

- The $k$ and $c$ parameters of the Weibull distribution show significant territorial variability being influenced by orographic conditions as well. In seasonal subdivision $k$ yields the highest value in spring and summer, while $c$ does so in winter and spring.

- There is a connection between the altitude above sea level of the measurement stations and the scale parameter value. $72.3 \%$ of the scale parameter's total variance can be explained by its linear connection with the altitude above sea level of the measurement point.

- By analyzing the frequency distribution of daily average wind speed and some of its statistical indices at anemometer altitude and at $80 \mathrm{~m}$ determined by means of Weibull distribution parameters, we can say that among the examined stations, the most favorable conditions to utilize wind energy are offered by the Play station situated on the Borzhava snow-covered mountain ridge. In vicinity of the measurement points located on plains and in narrow river valleys of highlands, there are no sufficient wind speeds for industrial utilization even at the altitude of $80 \mathrm{~m}$ above ground level. 


\section{References}

Azad, A.K., Rasul, M.G., and Yusaf, T., 2014: Statistical Diagnosis of the Best Weibull Methods for Wind Power Assessment for Agricultural Applications. Energies 7, 3056-3085. https://doi.org/10.3390/en7053056

Bartholy, J. and Radics, K. (Eds.), 2000: A szélenergia hasznosítás lehetőségei a Kárpát-medencében. Egyetemi Meteorológiai Füzetek. 14., Budapest. (in Hungarian)

Bonfils, S., 2011: Modeling wind speed and wind power distributions in Rwanda. Renew. Sustain. Energ. Rev. 15, 925-935. https://doi.org/10.1016/j.rser.2010.11.001

Costa Rocha, P.A., Coelho de Sousa, R., Freitas de Andrade, C., and Vieira da Silva, M.E., 2012: Comparison of seven numerical methods for determining Weibull parameters for wind energy generation in the northeast region of Brazil. Appl. Energ. 89, 395-400. https://doi.org/10.1016/j.apenergy.2011.08.003

Dévényi, D. and Gulyás, O., 1988: Matematikai statisztikai módszerek a meteorológiában. Tankönyvkiadó, Budapest. (in Hungarian)

Dokur, E. and Kurban, M., 2015: Wind Speed Potential Analysis Based on Weibull Distribution. Balkan J. Elect. Comput. Engin. 3, 231-235. https://doi.org/10.17694/bajece.72748

Henessey, J.P., 1977: Some aspects of wind power statistics. J. Appl. Met. 16, 119-128. https://doi.org/10.1175/1520-0450(1977)016<0119:SAOWPS $>2.0 . C O ; 2$

Hou, Y., Peng, Y., Johnson, A.L., and Shi, J., 2012: Empirical Analysis of Wind Power Potential at Multiple Heights for North Dakota Wind Observation Sites. Energ. Sci Technol 4, 1-9.

Hunyár, M., 2004: A szélenergia potenciál hasznosítását korlátozó tényezők Magyarországon. Magyar Energetika 4, 3-10. (in Hungarian)

Huzsvai, L. and Vincze, Sz., 2012: SPSS könyv. Seneca Books. (in Hungarian)

Justus, C.G., Hargraves, W.R., Amir, M., and Graber, D., 1978: Method for estimating wind speed frequency distributions. J. Appl. Meteor. 17, 350-353.

https://doi.org/10.1175/1520-0450(1978)017<0350:MFEWSF>2.0.CO;2

Kartashov, M.V., 2008: Probability, processes, statistics. ВПЦ „Київський університет”, Київ. (in Ukrainian)

Khan, P.A., Halder, P.K., and Rahman, S., 2014: Wind energy potential estimation for different regions of Bangladesh. Intern. J. Renew. Sustain. Energ. 3, 47-52. https://doi.org/10.11648/j.ijrse.20140303.11

Kidmo, D.K., Danwe, R., Doka, S.Y., and Djongyang, N., 2015: Statistical analysis of wind speed distribution based on six Weibull Methods for wind power evaluation in Garoua, Cameroon. Rev. Energ. Renouvel. 18, N1, 105-125.

Kravchyshyn, V.S., Medykovskyi, M.O., and Halushchak,M.O., 2016: Modelling the energetic potential of a wind power station. Вісник Національного університету "Львівська політехніка". Серія: Інформаційні системи та мережі 854, 80-87. (in Ukrainian)

Lavny, $i$ V. and Lässig, R., 2009: Strong Winds in the Ukrainian Carpathians [Characteristics of Storms in the Ukrainian Carpathians]. Науковий вісник НЛТУ України, вип. 19.14., Львів, 239-246. (in Ukrainian)

Liubimov, O.D., Kovalenko V.M., and Chubenko A.I., 2011: Methods of processing statistical data on wind parameters to make the decision to place a wind power station in a specific region. Електроніка та системи управління, 2 (28), 116-119. (in Ukrainian)

Maklad, Y. and Glencross-Grant, R., 2014: A Seasonal Analysis of Potential Wind Power for Armidale NSW, Australia. Int. J. Energ. Econom. Policy 4, 92-107.

https://doi.org/10.9790/3021-04910932

Matyasovszky I., 2002: Statisztikus klimatológia. Idősorok elemzése. ELTE Eötvös Kiadó, Budapest. (in Hungarian)

Morgan, E.C., Lackner, M., Vogel, M.R., and Baise, G.L., 2011: Probability distributions for offshore wind speeds. Energ. Convers. Manage. 52, 15-26. https://doi.org/10.1016/j.enconman.2010.06.015

Patay, I., 2003: A szélenergia hasznosítása. Szaktudás Kiadó Ház, Budapest. (in Hungarian) 
Radics, K., 2004: A szélenergia hasznosításának lehetőségei Magyarországon: hazánk szélklímája, a rendelkezésre álló szélenergia becslése és modellezése. Doktori értekezés, ELTE, Budapest. (in Hungarian)

Şahini, Z.A. and Aksakal, A., 1999: A Statistical Analysis of Wind Energy Potential at the Eastern Region of Saudi Arabia, Int. J. Energy Res. 23, 909-917. https://doi.org/10.1002/(SICI)1099-114X(199908)23:10<909::AID-ER529>3.0.CO;2-1

Schönwiese, C.-D., 2013: Practical Statistics for Meteorologists and Geoscientists. 5. Vollständig überarbeitete und erweiterte Auflage. Gebrüder Borntraeger Verlagsbuchhandlung, Stuttgart.

Sobchenko, A. and Khomenko, I., 2015: Assessment of regional wind energy resources over Ukraine. Energy Procedia, 76, 156-163. https://doi.org/10.1016/j.egypro.2015.07.889

Tar, K., 2008: Some statistical characteristics of monthly average wind speed at various heights. Renew. Sustain. Energ. Rev. 12, 1712-1724. https://doi.org/10.1016/j.rser.2007.01.014

Troen, I. and Petersen, L., 1989: European Wind Atlas. Risø Nat. Labs, Roskilde, Denmark.

Xydis, G., 2012: Wind-direction analysis in coastal mountainous sites: An experimental study within the Gulf of Corinth, Greece. Energ. Conver. Manage. 64, 157-169.

https://doi.org/10.1016/j.enconman.2012.05.018 